DOI: $10.1515 / \mathrm{rpp}-2017-0059$

Postgraduate Student, YULIIA ILIASOVA Vinnytsia State Pedagogical University named after Mykhailo Kotsiubynskyi Address: 32 Ostrozkyi St., Vinnytsia, 21100, Ukraine E-mail: iyulya72@ukr.net

\title{
PROFESSIONAL TRAINING OF JUNIOR MEDICAL STAFF: EUROPEAN EXPERIENCE
}

\begin{abstract}
The article covers current problems of professional training of junior medical staff. The main disadvantages of Ukrainian system of medical education that impede the intention of improving quality of professional training of junior medical staff have been analyzed. European experience in organizing medical education, namely, in Great Britain, Georgia, Italy, Poland and France has been studied. It has been determined that foreign experience in training medical junior staff differs from that in Ukraine. Comparative characterization of European and Ukrainian experience in training future nurses and midwives has been presented. The advantages of European professional training of future medical junior staff have been highlighted. It has been found out that in Europe more attention is paid to clinical disciplines than in Ukraine due to an increase in the number of academic hours allocated for practical training at clinical sites. The author emphasizes importance of independence in the process of training future junior medical staff in European educational space. The need for introducing into the education process of professional medical training in Ukraine communicative disciplines, including Pedagogy, which have long been used in medical education in Europe, has been specified. The author has considered the main features of apprenticeship being a new form of training in Ukrainian medical education that combines theoretical training and paid hospital placement. It has been concluded about European innovative trends in Ukrainian medical industry and gradual introduction of continuing consecutive education. It has been stressed that it is rather relevant to incorporate positive aspects of foreign experience in organizing medical education into modern reforms as well as new curricula in Ukraine.

Keywords: professional training, medical education, European experience, junior medical staff.
\end{abstract}

\section{INTRODUCTION}

Ukraine is gradually approaching Europe and introducing European standards. The reforms in medical education are mostly aimed at enhacing quality and effectiveness of nurses' professional training, which combines three specializations, namely, Nursing, Nursing and Midwifery, Critical Care Nursing.

The problem of professional medical training has been studied by both Ukrainian specialists and foreign medical staff. They constantly confirm importance of its study and consider it necessary to adjust the national standards of medical education to European ones.

\section{THE AIM OF THE STUDY}

The aim of the study is to specify European experience in organizing professional training of junior medical staff, conduct comparative analysis on the process of professional training of future junior medical staff in Europe and Ukraine. 


\section{THEORETICAL FRAMEWORK AND RESEARCH METHODS}

Thus, the problem of professional training of junior medical staff, including nurses and midwifes, is rather topical in general and for the educational space of Ukraine in particular. Ukrainian educators have been actively updating the national system of professional training of various specialists, in particular nurses and midwives, so it is extremely relevant to implement the best practices of European countries into the education process of professional training nurses and midwives at native medical education institutions. For this purpose, we have studied British, French, Italian, Polish and Georgian experience in organizing professional training of nurses and midwives. In addition, we have applied to the works by Ukrainian (L. Lohush, N. Hernandez et al.) and foreign (F. Baldassarre, M. Dzhharkava, E. Harlashyna et al.) scholars who have covered this very problems in their studies.

The problem of professional training of junior medical staff has been studied based on comparative analysis of research findings of foreign scholars on European experience

\section{RESULTS}

Within this article, we would like to consider peculiarities of modern professional training of junior medical staff, in particular nurses and midwives, based on the experience of European educational and medical space. It should be mentioned that in the EU countries there is no such occupation as a junior medical specialist. However, there are similar occupations, including nurses and midwives, who are considered to be additional medical staff. In addition, in Europe there is no such occupation as a feldsher, that is a medical doctor's assistant.

S. Yastremska (2017) has studied development of continuing consecutive medical education in Europe. The author states that "nursing education in European countries is provided by nursing schools, colleges, institutes, universities and academies. In order to become a certified nurse, a future specialist is to study 3 (Greece, Estonia, Spain, Sweden) or 3,5 (Austria, Belgium, Great Britain, Denmark, the Netherlands) years. After that, they may continue their studies and obtain a Bachelor of Science (BSc) degree in Nursing (BSN, BScN)" (p. 511).

Great Britain is one of the countries, where the professions of nursing and midwifery are rather in demand. Middle-level medical staff in Great Britain are taught in medical schools and colleges. It must be noted that British courses on nursing and midwifery are characterized by narrow specialization. Thus, a nurse may simultaneously study and work in one of the following fields: adult nursing, pediatric nursing, psychiatric nursing and developental disability nursing (Royal College of Nursing, 2017). In Great Britain, the profession of midwifery is rather complicated and unique. Such specialists deal with pregnant women, fully support them, provide them and newborns with prenatal and postnatal care, assist families in preparing for their parentrhood. In Great Britain, midwives work at public health facilities, maternity hospitals, communities and adolescent pregnancy clinics. To become a midwife, one must study at a medical school or college for three years. Certified nurses may apply for a 18-month shortened programme in Midwifery. After obtaining medical education, all nurses and midwives must be registered with the Nursing and Midwifery Council (NMC) for further employment (Royal College of Nursing, 2017).

Also we would like to consider teaching methodology of clinical disciplines based on the experience of Canterbury Christ Church University. In Great Britain, much attention is paid to studying clinical disciplines. The students of medical schools, colleges and universities train practical skills using simulators and in simulation rooms. Rather innovative we find 
teaching of clinical disciplines using simulation wards located in education institutions. These wards are equipped with all the facilities needed in professional medical activity, namely, future specialists can learn to examine patients as well as provide them with care or critical care. In addition, there are simulation mannequins in simulation wards. Nursing students also work in maternity and pediatric simulation wards, which are equipped with modern medical equipment and familiarize the students with a realistic clinical setting so that which they may train their skills and apply their knowledge in practice. In our opinion, such an organization of practical classes is completely adjuted with the structure of context-based learning.

Quite relevant is the introduction of quasi professional activity, as the main form of context-based learning during studying surgery based on the example of an operating theater and a scrub room. The one-way mirror separates the observation room and the operativing theater. In the observation room, teachers not only monitor their students' work, but also evaluate their actions (Canterbury Christ Church University, 2017).

We believe it necessary to consider professional training of nurses and midwives in the process of studying clinical disciplines at the University of York. At the University, there is a Clinical Simulation Unit (CSU) that presents great opportunities for enhacning clinical skills. The CSU has two, four-bedded hospital bays, an intensive care suite and a bedsit. They also have a large versatile teaching area, which can be divided into multiple room configurations by modern, soundproofed, movable walls. The CSU is also equipped with high fidelity adult, junior and baby patient simulation mannequins which replicate a range of physiological signs and symptoms. These mannequins enable the students to practice responding to real time clinical scenarios including medical emergencies. To enhance the feedback given to the students, the CSU is equipped with excellent audio visual and IT equipment. They have a number of fixed and mobile cameras specifically designed for healthcare education. Video is held securely and playback can be done quickly on specific PCs or on a large touchscreen television (The University of York, 2017).

In our opinon, the use of simulation techniques significantly improves quality and effectiveness of such training, brings the students closer to real clinical scenarios, enables them to clearly and qualitatively enhance their practical skills. In Ukraine, second year medical students begin to study special disciplines and enhance practical skills with real patients. Early engagement of the students in a real clinical environment and contact with real patients develops their communicative abilities, as well as contributes to forming their deontological competency.

Georgia is one of the post-Soviet countries that is actively approaching Europe and where economic and social standards of living have improved considerably after a series of conducted reforms. Georgian educational institutions prepare highly qualified nurses. The profession of nursing can be obtained both at state and private medical universities. There are four-year bachelor programmes in nursing and two-year-and-a-half professional programmes for nursing practitioners there. In order to apply for a bachelor programme, one must pass Unifed National Exams (UNE) and for a professional nursing programme obtain 12-year secondary education and pass a relevant exam. At Tbilisi State Medical University, a bachelor programme in nursing is provided in collaboration with Austrian colleagues. Future nurses, who have a good command of the German language, may undergo an internship in Austria. In Georgia, the emphasis is placed on communicative skills of nurses. M. Dzhharkava, a coordinator of professional programmes in nursing at Tbilisi State Medical University, has analyzed the state of nursing education in Georgia. He has concluded that "a modern Georgian nurse must not only possess professional knowledge 
and skills, but also be sociable. Communicating with a patient is a very complicated task. At the university, future nurses are taught communicative disciplines: Conflict Management, Communication Skills, etc." (Sputnik, 2017). We agree on the fact that it is expedient to introduce into the education process of medical education institutions communicative disciplines.

In Italy, junior medical staff obtain primary professional education at medical colleges. Based on the work by F. Baldassare (2010), we state that over the last 17 years in Italy a number of reforms in medical education have been introduced. According to the scholar, "the transition to university education has completed very fast: first nurses were expected to obtain a diploma of secondary medical education; after that they were allowed to assist doctors and had distinct professional roles; nowadays they must obtain three-year university education. Also they were granted an opportunity to continue their studies, namely, apply for a one-two year master programme. Many curricula provide wide career opportunities for individuals with basic education. It should be mentioned that hospitals do not consider them to be a free labour force nowadays and negotiate with universities in order to create conditions for high-quality clinical education" (Baldassarre, 2010).

Also we would like to consider professional training of junior medical staff in Poland. Medical education development in this country is especially important for our study. According to L. Lohush (2016), "after joining the European commonwealth, Poland actively pursued reforms and quickly reached a high level of economic and educational development. The strategy for transforming Polish education policy is an example of success, progressiveness and effectiveness of the state policy" (p. 77). Polish nurses and midwives are ranked third among the most in-demand professions in the labour market.

Analyzing professional training of junior medical specialists, V. Stasiuk (2016) compared the peculiarities of professional training of nurses in Poland and Ukraine. Thus, Polish bachelor programmes in nursing and Ukrainian programmes that presuppose obtaining a qualification of a junior medical specialist last three years and require the applicants to prior obtain complete secondary education. However, the number of academic hours allocated for professional training of nurses in Ukraine is significantly greater tham that in Poland. In addition, Ukrainian nurses study more academic disciplines than nursesbachelors in Poland. In Polish syllabi, one can find Pedagogy, Dietetics, Radiology, etc.

N. Hernandez (2012) has analyzed curricula and syllabi for nursing under the conditions of consecutive education in Poland and Ukraine. The scholar indicates that "humanites and socioeconomic disciplines in Ukrainian syllabi comprise 492 academic hours, whereas in Poland - 240-285 academic hours. According to practical training in clinical sites, comparative analysis shows that in Ukraine 486 academic hours are allocated for practical classes, whereas in Poland $-1200-1350$ academic hours (p. 54).

So, we have concluded that medical education in Ukraine is mainly based on studying humanities, social and natural sciences, whereas clinical disciplines, which mostly contribute to forming and developing professional knowledge and skills, are allocated much less time than in Poland. Moreover, in Poland the top priority is introduction in the education process a great number of hours allocated for practical training in clinical sites.

Ye. Kharlashyna (2015) has studied the state of professional training of future medical specialists in France. Thus, a nurse is considered to be additional medical staff in France. A midwife has a much higher status and equates to a group of medical professions, which include doctors and dentists. At medical education institutions in France, clinical disciplines are more preferred fundamental ones. Studying medical education in France, the scholar revealed the peculiarities of classes in medical education institutions. Theoretical 
training involves lectures for all students of the course. In France, lecture attendance is optional, therefore the students may search for information independently. However, the students must attend practical classes under the supersivion of the teacher. During practical classes, the students become active participants in the education process, solve complex tasks, develop clinical and creative thinking, as well as their cognitive activities, whereas the teacher is an observer, who coordinate the students' work.

E. Kharlashyna (2015) emphasizes that in France professional training of middlelevel medical staff is characterized by a great number of hours dedicated to practical (clinical) training "at the patient's bedside". Of great significance, in our opinion, is apprenticeship that combines theoretical training and paid hospital placement. However, it has some disadvantages, namely, the students are greatly overloaded, since they must constantly apply time management skills in order to cover both theoretical and practical training. According to French curricula for nursing, theoretical training comprises 1800 astronomical hours, and practical (clinical) training - 2100 astronomical hours.

\section{CONCLUSIONS}

So, we have concluded that there are certain differences in professional training of junior medical staff in Ukraine and in Europe. Thus, the advantages of European medical education are the following:

- top prority of clinical disciplines;

- allocation of most academic hours to practical training in clinical sites and stimulation rooms;

- promotion of future specialists' self-education;

- introduction of communicative disciplines into the education process of medical education institutions; institutions;

- introduction of Pedagogy into the education process of medical education

- involvement of experienced nurses into the process of training novice nurses and patients using innovative pedagogical methodologies and technologies;

- implementation of apprenticeship that combines theoretical and practical training into the education process of medical education institutions.

Having analyzed European experience in organizing medical education, we can conclude that Ukrainian medical education is actively pursuing new ways, in particular European ones. In Ukraine, one can observe gradual introduction of continuing consecutive education. We consider it expedient to emphasize that all positive aspects of European experience in organizing medical education can be used while planning modern reforms in Ukraine and developing new curricula and syllabi.

Rather perspective we consider the study of US experience in organizing professional training of nurses and midwifes at medical schools and colleges.

\section{REFERENCES}

1. Baldassarre, F. (2010). Sestrinskoe delo v XXI veke: tendentsii, problemy i perspektivyi (na primere Kanady, Italii i Chili). Meditsinskoye obrazovanie i professionalnoe razvitie, 2, 30-40.

2. Canterbury Christ Church University. (2017). Simulation suites. Retrieved from https://www.canterbury.ac.uk/health-and-wellbeing/simulation-suite/simulation-suite.aspx. 
3. Harlashyna, E. (2015). Rol innovatsionnyih tehnologiy v protsesse professionalnoy podgotovki srednego meditsinskogo personala vo Frantsii. Materialyi V Mezhdunarodnoy nauchno-prakticheskoi konferentsii. Cheboksary: Interaktiv plus.

4. Hernandes, N. (2012). Osoblyvosti vyshchoi medsestrynskoi osvity v Polshchi $i$ $v$ Ukraini. Materialy Vseukrainskoi naukovo-praktychnoi konferentsii "Vyshcha osvita $\mathrm{V}$ medsestrynstvi: problemy i perspektyvy". Zhytomyr: Zhytomyrskyi instytut medsestrynstva.

5. Lohush, L. (2016). Tendentsii rozvytku medychnoi osvity v osvitnii politytsi Yevropeiskoho Soiuzu. (Dys. kand. ped. nauk). Kyivskyi universytet imeni Borysa Hrinchenka, Kyiv.

6. Royal College of Nursing. (2017). Become a midwife. Retrieved from https://www.rcn.org.uk/professional-development/become-a-midwife.

7. Royal College of Nursing. (2017). Become a nurse. Retrieved from https://www.rcn.org.uk/professional-development/become-a-nurse.

8. Sputnik. (2017). Riadom v trudnuiu mynutu: nezamenymaia y nedootsenennaia professyia medsestry. Vziato s https://sputnik-georgia.ru/reviews/20170512/235954375/ Miloserdie-kazhdyj-den-medsestry-otmechajut-svoj-prazdnik.html

9. Stasiuk, V. (2016, Kviten 15). Kryza medsestrynstva v Ukraini: chy vriatuie nova kontseptsiia? (15.04.2016). Medychna hazeta Ukrainy. Vashe zdorovia, 15-16, 8-10.

10. The University of York. (2017). Clinical simulation unit (CSU). Retrieved from https://www.york.ac.uk/healthsciences/study/facilities/.

11. Yastremska, S. (2017). Retrospektyvnyi analiz naukovykh peredumov stanovlennia svitovoi ta vitchyznianoi system medsestrynskoi osvity. Molodyi vchenyi, 44 (4), 510-514. 